\title{
Prediction of Relapse After Therapy Withdrawal in Women with Endometrial Hyperplasia: A Long-term Follow-up Study
}

\author{
ELISE THORESEN SLETTEN ${ }^{1}$, MARIT ARNES ${ }^{2}$, LENA MYRENG LYSA ${ }^{3}$, \\ BJORN TG $\mathrm{MOE}^{3}$, BJORN STRAUME ${ }^{4}$ and ANNE ORBO ${ }^{2,3}$ \\ ${ }^{1}$ Department of Gynecologic Oncology, Clinic for Surgery, Cancer and Women's Diseases, \\ University Hospital of North Norway, Tromso, Norway; \\ ${ }^{2}$ Research Group for Gynecologic Oncology, Department of Medical Biology, and \\ ${ }^{4}$ Department of Community Medicine, Faculty of Health Sciences, University of Tromso, Tromso, Norway; \\ ${ }^{3}$ Department of Clinical Pathology, University Hospital of Tromso, Tromso, Norway
}

\begin{abstract}
Aim: To investigate whether risk of relapse of endometrial hyperplasia persists many years after successful primary therapy and whether clinical or biological markers observed at primary diagnosis may predict relapse. Materials and Methods: A series of 57 women with endometrial hyperplasia received levonorgestrel-impregnated intrauterine system or oral progestin for three months during 1998-2000. Index biopsies were classified according to WHO1994 and D-score systems, and immunohistochemical staining for estrogen receptor $\alpha(E R \alpha)$, estrogen receptor $\beta$ $(E R \beta)$, progesterone receptor $A(P R A)$, progesterone receptor $B$ (PRB), B-cell lymphoma 2/apoptosis regulator (BCL2), $B C L 2$-associated $X$ protein/apoptosis regulator $(B A X)$, paired box 2 (PAX2), and phosphatase and tensin homolog (PTEN) reported as H-scores. Results: Over a follow-up of 157.8 months, 23\% (10/43) of patients experienced relapse. No correlation with age, body mass index, parity, WHO94 classification, or D-score was found. Only PRA ( $p=0.004)$ and PRB ( $p=0.038)$ showed certain correlation with relapse. Conclusion: Endometrial hyperplasia recurs many years after successful progestin therapy. Increased expression of $P R B$ and reduced expression of PRA significantly correlated with relapse. Our results support the importance of continuous endometrial protection and the need for new clinical surveillance guidelines.
\end{abstract}

This article is freely accessible online.

Correspondence to: Professor Anne Ørbo, Research Group for Gynecologic Oncology, Department of Medical Biology, Faculty of Health Sciences, University of Troms $\varnothing$, N-9037 Troms $\varnothing$, Norway. Tel: +47 77627220. Fax: +47 77627204, e-mail: anne.orbo@uit.no

Key Words: Medium and low-risk endometrial hyperplasia, progestin therapy, relapse after therapy response.
Endometrial carcinoma is the most common malignancy of the female genital tract, and its incidence is continuously increasing (1, 2). Approximately $80 \%$ of endometrial carcinomas (type I) are preceded by preliminary stages, known as endometrial hyperplasia, and one in five cases of hyperplasia will progress to cancer if left untreated (3). During the past several decades, oral hormonal therapy with progestin has been occasionally used as therapy for endometrial hyperplasia as an alternative to surgery (4-7). Recent evidence suggests that the levonorgestrel-impregnated intrauterine system (LNG-IUS) is superior to oral therapy and can be successfully used in endometrial hyperplasia to prevent disease progression (7-12). The risk of relapse remains even after regression of endometrial hyperplasia has been achieved, but there is no international consensus on the duration of surveillance after successful treatment, nor any recommendation with regard to follow-up schedule. Although some studies have found that the risk of relapse is higher after oral therapy compared to intrauterine therapy, the frequency of relapse after treatment withdrawal varied from $13.7 \%$ to $43 \%$ in various patient populations $(7,13,14)$.

Specific and safe prognostic methods to identify women at risk of relapse do not exist, and thus far only one long-term study has validated clinical and biological markers as predictors of relapse $(7,13,14)$. The pathogenesis of malignant transformation of the endometrium is not completely understood, but it is generally accepted that such malignancies result from estrogen-driven changes unopposed by progesterone, in combination with underlying genetic aberrations (15-20). B-cell lymphoma 2 (BCL2) and BCL2associated $\mathrm{X}$ protein (BAX) are proteins involved in the regulation of programmed cell death, and both have been shown to be significantly down-regulated in endometrial glands but up-regulated in the stroma in patients with complete regression of hyperplasia after successful progestin therapy $(17,18,21-23)$. Inactivation of the tumor-suppressor 
genes phosphatase and tensin homolog $(P T E N)$ and paired box gene 2 (PAX2) by mutation, deletion or clonal loss has been demonstrated to occur in the preliminary stages of endometrial cancer in up to $63 \%$ and $71 \%$ of cases, respectively $(18,24$, $25)$. For both genes, clearance of mutated clones was demonstrated after successful progestin therapy $(25,26)$. However, the correlation between expression levels of estrogen receptors (ER $\alpha, E R \beta)$, progesterone receptors (PRA, PRB), BCL2, BAX, PTEN and PAX and relapse after successful therapy remains to be investigated.

In the present observational, population-based cohort study, women with low- and medium-risk endometrial hyperplasia were followed-up and examined for relapse for more than 150 months. To the best of our knowledge, no other patient database with a comparable duration of follow-up exists. Our aim was to determine whether any clinical or biological markers observed and available at the time of primary diagnosis were important in predicting the individual risk of relapse. Identifying such markers could pave the way for individualized therapy and closer followup for high-risk patients, as well as the development of new and safer clinical guidelines. Thus, clinical and demographic data, as well as the immunohistochemical expression profiles of the index biopsies, were validated as predictors of relapse.

\section{Materials and Methods}

Study population. Two population-based series of patients with histologically confirmed endometrial hyperplasia were assembled during 1998-2000. The first group, which included 26 women between 30 and 70 years of age, received treatment with LNGIUS (Mirena ${ }^{\circledR}$, Bayer releasing $20 \mu \mathrm{g}$ levonorgestrel/day) for 3 months. The other group, which included 31 consecutive patients between 30 and 70 years of age, received cyclic oral progestin therapy [medroxyprogesterone (MPA) $10 \mathrm{mg}$ daily for 10 days a month repeated for 3 cycles]. The medication had been chosen and administered by the patients' local gynecologists according to therapy recommendations at that time. All women were enrolled after providing informed consent. Prior to enrolment, index endometrial biopsies were obtained by suction biopsy $(\mathrm{N}=22)$ or dilatation and curettage $(\mathrm{D} \& \mathrm{C})(\mathrm{N}=35)$. The most frequent symptoms were menometrorrhagia and postmenopausal bleeding.

To evaluate response to therapy, a control endometrial biopsy was obtained after 3 months. Independent of response to therapy, all study participants received long-term follow-up. The choice of further treatment and surveillance in women who experienced relapse after completing the study was left to their primary gynecologists and was based on individual patient requirements and medical recommendations at that time. Follow-up time for each patient was calculated from the date of the index biopsy until 1 January 2016 or until hysterectomy or death. Relapse was considered as an outcome only in women who responded after 3 months of primary therapy. All patient records were systematically reviewed through the electronic record system used in our health region.
Biopsy materials. Gynecologists at outpatient clinics in northern Norway were responsible for the sampling of endometrial biopsies. All index biopsies, control biopsies and additional biopsies during follow-up were sent to the Department of Pathology at the University Hospital of North Norway for routine assessment. The specimens were fixed in buffered formaldehyde, embedded in paraffin and further processed in the laboratory before standard histological sections were made. In accordance with routine diagnostic procedures, a trained gynecological pathologist (AO) and one additional general pathologist, both of whom were blinded to each other's diagnoses, performed histological assessments according to the WHO94 classification (3) using light microscopy. In cases of discordant results, a consensus was always obtained after discussion at a two-headed microscope. The index biopsies were classified into one of three groups according to the WHO94 classification, which was considered the gold standard for evaluation of endometrial hyperplasia at the time the study was performed: simple hyperplasia, complex hyperplasia or atypical hyperplasia (3). Response to primary therapy was defined by the finding of ordinary proliferative endometrium or endometrium with progestin-induced changes in the control biopsy. Persistent hyperplasia in the control biopsy was graded according to the WHO94 classification and defined as primary therapy failure. Additional biopsies obtained during follow-up were evaluated and classified in the same manner. All information from the WHO94 classification of the index, control and additional endometrial biopsies was recorded and maintained in a separate database and subsequently supplemented with information from hospital records.

Morphometric analysis D-score. After diagnostic microscopy was completed and consensus was reached on the WHO94 classification, tissue morphometry and D-score analyses were conducted to improve risk stratification. The D-score method has been shown to be superior to WHO94 classification in predicting cancer outcomes $(10,17,27-30)$. Patients with a D-score $<0$ are considered to have a high risk of co-existent or future carcinoma, and hysterectomy is recommended in such cases. Thus, only patients with D-scores 0 or greater were eligible for the study, and they all received conservative regimens and long-term follow-up. The D-score analyses were performed by trained technicians. The initial study of computerized morphometric analysis of endometrial hyperplasia included a total of 10 nuclear features and 12 architectural features. Using stepwise linear regression and discriminant analysis, three of these quantitative features were selected as having significant independent prognostic value and were combined into a formula known as the D-score, as follows: $\mathrm{D}$-score $=0.6229+0.0439 \times$ (volume percentage stroma) $-3.9934 \times \mathrm{Ln}$ (standard deviation of shortest nuclear axis) $-0.1592 \times$ (outer surface of density glands), where $\mathrm{Ln}$ is the natural logarithm. The measurements were performed using a Q-PRODIT image analysis system (version 6.1, Leica, Cambridge, UK). The D-score method has been described in detail in previous studies $(10,17,27-30)$.

Immunohistochemistry. Sections from the index biopsies of women who responded to primary therapy were immunostained for expression of ERa, ER $\beta$, PRA, PRB, ER $\alpha$, ER $\beta$, BCL2, BAX, PTEN and PAX2. However, due to insufficient material in the paraffin blocks, immunostaining was not performed for all cases (for ER $\alpha$ and BCL2, material was available for nine cases of relapse and 27 cases of sustained response; for ER $\beta, P R A, P R B$, and BAX, 
Table I. Immunohistochemical staining methods for each of the markers investigated in the present study.

\begin{tabular}{|c|c|c|c|c|c|c|c|c|}
\hline & $\begin{array}{c}\text { Estrogen } \\
\text { receptor } \\
(\mathrm{ER} \alpha)\end{array}$ & $\begin{array}{c}\text { Estrogen } \\
\text { receptor } \\
(\mathrm{ER} \beta)\end{array}$ & $\begin{array}{l}\text { Progesterone } \\
\text { receptor } \\
\text { (PRA) }\end{array}$ & $\begin{array}{l}\text { Progesterone } \\
\text { receptor } \\
(\mathrm{PRB})\end{array}$ & $\begin{array}{l}\text { B-Cell lymphoma } \\
\text { 2/apoptosis } \\
\text { regulator (BCL2) }\end{array}$ & $\begin{array}{l}\text { BCL2-associated } \\
\text { X protein/apoptosis } \\
\text { regulator BAX }\end{array}$ & $\begin{array}{l}\text { Paired } \\
\text { box } 2 \\
(\mathrm{PAX} 2)\end{array}$ & $\begin{array}{c}\text { Phosphatase and } \\
\text { tensin homolog } \\
\text { (PTEN) }\end{array}$ \\
\hline Antibody & $\begin{array}{c}\text { NCL-ER-6F11 } \\
\text { Estrogen } \\
\text { A mouse } \\
\text { monoclonal } \\
\text { Clone: } 6 \mathrm{~F} 11\end{array}$ & $\begin{array}{l}\text { NCL-ER- } \beta \\
\text { Estrogen } \\
\text { mouse } \\
\text { monoclonal } \\
\text { Clone: } \\
\text { EMR02 }\end{array}$ & $\begin{array}{c}\text { NLC-PGR-312 } \\
\text { PGR-A } \\
\text { mouse } \\
\text { monoclonal } \\
\text { Clone: } 16\end{array}$ & $\begin{array}{c}\text { NCL-PGR-B } \\
\text { PRG-B } \\
\text { mouse } \\
\text { monoclonal } \\
\text { Clone: } \\
\text { SAN27 }\end{array}$ & $\begin{array}{c}\text { Mouse } \\
\text { monoclonal } \\
\text { anti-human } \\
\text { BCL2 } \\
\text { oncoprotein. } \\
\text { Code. No. M } \\
\text { 0887 Clone: } \\
124 .\end{array}$ & $\begin{array}{c}\text { Rabbit } \\
\text { polyclonal } \\
\text { anti-human } \\
\text { BAX. Code } \\
\text { no: A3533 } \\
\text { Lot } 057\end{array}$ & $\begin{array}{c}\text { Rabbit } \\
\text { polyclonal } \\
\text { anti-PAX2 } \\
\text { Code no: } \\
\text { 311R-15 } \\
\text { Clone: } \\
\text { EP235 }\end{array}$ & $\begin{array}{c}\text { Monoclonal } \\
\text { mouse } \\
\text { anti-human } \\
\text { PTEN Code } \\
\text { no: M5182 } \\
\text { Clone: SP218 }\end{array}$ \\
\hline Manufacturer & \multicolumn{2}{|c|}{$\begin{array}{c}\text { Novocastra, Newcastle } \\
\text { upon Tyne, UK }\end{array}$} & \multicolumn{2}{|c|}{$\begin{array}{l}\text { DakoCytomation, } \\
\text { Glostrup, Denmark }\end{array}$} & \multicolumn{2}{|c|}{$\begin{array}{c}\text { AH-Diagnostics as. } \\
\text { Cell Marque, CA, USA }\end{array}$} & \multicolumn{2}{|c|}{$\begin{array}{l}\text { Springer Bioscience, } \\
\text { CA., USA. }\end{array}$} \\
\hline Pretreatment & $\begin{array}{c}\text { Manual } \\
\text { method. } \\
\text { Pressure } \\
\text { cooker } \\
3 \text { minutes. } \\
\text { Citrate } \\
\text { buffer pH } 6 .\end{array}$ & $\begin{array}{c}\text { Manual } \\
\text { method. } \\
\text { Pressure } \\
\text { cooker } \\
3 \text { minutes. } \\
\text { Citrate } \\
\text { buffer pH } 7\end{array}$ & $\begin{array}{c}\text { Manual } \\
\text { method. } \\
\text { Pressure } \\
\text { cooker } \\
3 \text { minutes. } \\
\text { Citrate } \\
\text { buffer pH } 6\end{array}$ & $\begin{array}{c}\text { Manual } \\
\text { method. } \\
\text { Pressure } \\
\text { cooker } \\
3 \text { minutes. } \\
\text { Citrate } \\
\text { buffer pH } 6\end{array}$ & $\begin{array}{c}\text { Manual } \\
\text { method. } \\
\text { Pressure } \\
\text { cooker } \\
5 \text { minutes. } \\
\text { Citrate } \\
\text { buffer pH } 7\end{array}$ & $\begin{array}{c}\text { Manual } \\
\text { method. } \\
\text { Water bath } \\
95-99^{\circ} \mathrm{C} \\
40 \text { minutes. } \\
\text { Citrate } \\
\text { buffer pH } 6\end{array}$ & $\begin{array}{r}\text { Automated. Tr } \\
\text { reagent } 32 \mathrm{~m} \\
\text { Benchmark UI } \\
\text { IHC/ISH } \\
\text { system. Ve } \\
\text { Systems, } \\
\text { AZ }\end{array}$ & $\begin{array}{l}\text { ris-based alkaline } \\
\text { minutes. Ventana } \\
\text { LTRA Automated } \\
\text { slide staining } \\
\text { entana Medical } \\
\text {, Inc. Tucson } \\
\text { z., USA }\end{array}$ \\
\hline Dilution & $\begin{array}{c}\text { 1:100. Ventana } \\
\text { antibody } \\
\text { diluent }\end{array}$ & $\begin{array}{l}1: 25, \text { Dako } \\
\text { antibody } \\
\text { diluent }\end{array}$ & $\begin{array}{c}\text { 1:200. Ventana } \\
\text { antibody } \\
\text { diluent }\end{array}$ & $\begin{array}{c}\text { 1:50. Ventana } \\
\text { antibody } \\
\text { diluent }\end{array}$ & $\begin{array}{c}\text { 1:50. Ventana } \\
\text { antibody } \\
\text { diluent }\end{array}$ & $\begin{array}{c}\text { 1:50. Ventana } \\
\text { antibody } \\
\text { diluent }\end{array}$ & $\begin{array}{l}\text { 1:50. Ventana } \\
\text { antibody } \\
\text { diluent }\end{array}$ & $\begin{array}{c}\text { a 1:150. Ventana } \\
\text { antibody } \\
\text { diluent }\end{array}$ \\
\hline $\begin{array}{l}\text { Incubation } \\
\text { time }\end{array}$ & $\begin{array}{l}32 \text { minutes, } \\
37^{\circ} \mathrm{C}\end{array}$ & $\begin{array}{l}40 \text { minutes, } \\
20^{\circ} \mathrm{C}\end{array}$ & $\begin{array}{l}32 \text { minutes, } \\
37^{\circ} \mathrm{C}\end{array}$ & $\begin{array}{l}32 \text { minutes, } \\
37^{\circ} \mathrm{C}\end{array}$ & $\begin{array}{l}28 \text { minutes, } \\
37^{\circ} \mathrm{C}\end{array}$ & $\begin{array}{l}40 \text { minutes, } \\
37^{\circ} \mathrm{C}\end{array}$ & $\begin{array}{l}55 \text { minutes, } \\
37^{\circ} \mathrm{C}\end{array}$ & $\begin{array}{l}50 \text { minutes, } \\
20^{\circ} \mathrm{C}\end{array}$ \\
\hline Detection & $\begin{array}{l}\text { Automated. } \\
\text { iView DAB D } \\
\text { detection } \\
\text { Kit, Ventana } \\
\text { Medical } \\
\text { Systems }\end{array}$ & $\begin{array}{c}\text { Manual method. } \\
\text { DakoCytomation } \\
\text { EnVision + } \\
\text { Dual Link } \\
\text { system-HRP } \\
\text { (DAB+) kit, } \\
\text { DakoCytomation }\end{array}$ & $\begin{array}{r}\text { Automated. } \\
\text { detection K } \\
\text { Medical }\end{array}$ & $\begin{array}{l}\text { iView DAB } \\
\text { Kit, Ventana } \\
\text { Systems }\end{array}$ & $\begin{array}{l}\text { Manual method } \\
\text { EnVision + Dua } \\
(\mathrm{DAB}+) \mathrm{kit},\end{array}$ & $\begin{array}{l}\text { DakoCytomation } \\
1 \text { Link system-HRP } \\
\text { DakoCytomation }\end{array}$ & $\begin{array}{l}\text { Automatec } \\
\text { DAB IHC I } \\
\text { Ventana Me }\end{array}$ & $\begin{array}{l}\text { d. UltraView } \\
\text { Detection Kit, } \\
\text { edical Systems }\end{array}$ \\
\hline
\end{tabular}

Enhancement

1. $0.05 \%$ Glutaraldehyde, 4 minutes. 2. Amplification kit, Ventana Medical Systems nine cases of relapse and 28 cases of sustained response; and for PTEN and PAX2, eight cases of relapse and 32 cases of sustained response). Staining procedures were performed as outlined in Table I. Prior to staining, histological slices ( $5 \mu \mathrm{m}$ thick) were cut from paraffin blocks using routine methods, placed on Superfrost+ glass slides and incubated overnight at $60^{\circ} \mathrm{C}$. Counterstaining was performed manually in three steps: hematoxylin staining, dehydration and clearing with xylene.

Assessment of $E R \alpha, E R \beta, P R A, P R B, B C L 2$ and BAX expression. Immunostaining for ER $\alpha, \mathrm{ER} \beta$, PRA, PRB, BCL2 and BAX was evaluated semi-quantitatively using an immunohistochemical histological score (H-score), which incorporates both the intensity and the distribution of specific staining. The $\mathrm{H}$-score is defined as $\mathrm{HS}=\sum(\mathrm{Pi} \times \mathrm{i}) / 100$. where Pi denotes the percentage of stained cells, and $\mathrm{i}$ denotes the intensity of staining ranging from 1 to 3 (31). Expression in the glands and in the stroma was evaluated separately for each specimen. Hot spots (areas with the strongest immunostaining) with a diameter of one $\mathrm{cm}$ were examined at $\times 40$ magnification. Both the intensity of staining and the number of stainpositive cells were counted. Samples with less than $10 \%$ positive cells were considered to be receptor-negative and given a score of zero. Samples with more than $10 \%$ positively stained cells were considered receptor-positive, and the percentage of positively stained cells was 
used to compute the $\mathrm{H}$-score. The $\mathrm{H}$-score scale ranged from 0 to 3 : A score of zero indicated the absence of staining, while scores of 1 , 2 and 3 indicated weak, moderate and strong immunoreactivity, respectively. The $\mathrm{H}$-score was assessed by a trained gynecological pathologist (AO) who was blinded to the original diagnosis, treatment group and treatment response.

Assessment of PAX2 and PTEN expression. Histological specimens stained for PAX2 and PTEN were examined under a light microscope by a trained gynecological pathologist (AO) and a trained technician (MA). A slide was assessed as PTEN-null or PAX2-null if one or more endometrial glands devoid of PAX2 or PTEN protein staining were observed. When all endometrial glands visualized expressed PAX2 or PTEN, the specimen was considered normal. Null glands were generally devoid of PAX2 or PTEN protein in all cells. The presence or absence of staining was always judged by consensus between the two investigators, using a twoheaded microscope. This procedure was always performed twice, with the examiners blinded to the patient outcomes. Loss of PAX2 and PTEN immunostaining was mostly characterized by an overlapping pattern occurring in the same foci.

Statistics. Statistical analyses were performed using STATA version 14 software (STATA Corp., College Station, TX, USA). Data are presented using standard descriptive statistics chi-squared and two-sample $t$-tests were used for comparisons of categorical and continuous variables, as appropriate. $p$-Values of less than 0.05 were considered significant.

Ethical approval. The study was approved by the Regional Committee for Medical and Health Research Ethics (approval numbers PREKNORD17/2002 and 23/2004), the Norwegian Council of Medical Advice and the Norwegian Medicines Agency.

\section{Results}

Patients. Women in the two treatment groups exhibited similar baseline characteristics with respect to age, body mass index, parity, histological WHO94 diagnosis and D-score distribution prior to therapy (32). All patients treated with LNG-IUS showed excellent response, with complete regression of hyperplastic endometrium after 3 months of therapy. In contrast, only 55\% (17/31) of patients in the oral MPA group achieved treatment response (Figure 1). Independently of the initial response to therapy, all women in the present study received long-term follow-up, with a mean follow-up time of 155.4 months. Endometrial surveillance was conducted using vaginal ultrasound and endometrial biopsies. A median number of 5.0 endometrial biopsies were obtained for each patient (range $=2-15$ ). One patient died of colon cancer during follow-up. All the remaining women were alive and still residing in northern Norway at the end of the follow-up period. Four women were diagnosed with invasive breast cancer, one with breast carcinoma in situ, one with ovarian cancer, and one with malignant melanoma.

Long-term follow-up and relapse after response to primary therapy. Overall, 43 women achieved a response to primary therapy: $26 / 26$ in the LNG-IUS group and 17/31 in the oral MPA group. During a mean follow-up of 157.8 (range=5-212) months, 10 (23\%) of the 43 women who initially responded to therapy experienced a relapse of endometrial hyperplasia. Patients diagnosed with relapse had undergone comparable surveillance regimens to patients with no relapse, with a median of five (range $=3-10$ ) endometrial biopsies obtained in the relapse group and four (range=2-9) in the sustained response group. The mean duration of follow-up among relapsing patients was 123.7 months, compared to 168.1 months in patients who did not experience relapse. The frequency of relapse was similar in the two treatment groups: $6 / 26(23 \%)$ in the LNG-IUS group and 4/17 (23.5\%) in the oral MPA group (Figure 1). Although most patients $(7 / 10,70 \%)$ relapsed within the first 2 years after withdrawal of progestin therapy, relapses were observed up to 10 years after the initial treatment.

Long-term follow-up in women with primary therapy failure. Various therapeutic procedures were offered to the women who showed persistent disease after three months of oral MPA therapy $(n=14)$. Five women underwent hysterectomy, one underwent trans-cervical endometrial resection, four received additional oral MPA therapy, and four had spontaneous regression. None of these women developed endometrial cancer during the observation period. This patient group had a mean follow-up of $148.2($ range $=20-212)$ months, and a median of four (range $=3-15$ ) endometrial biopsies were collected per patient.

Predictive markers for relapse in women with response to primary therapy. Only women who responded to primary therapy $(n=43)$ were evaluated with respect to relapse of endometrial hyperplasia. Evaluation of the prognostic significance of various clinical characteristics did not show any relationship with relapse (Table II). Clinical and histological characteristics of women who experienced relapse are shown in Table III. H-Scores for ER $\alpha, E R \beta$, PRA, PRB, BCL2, or BAX in the glands and in the stroma of index biopsies were not associated with relapse, with the exception of the H-scores for PRA in the stroma and for PRB in glands. Between women with and those without relapse there was significant difference in $\mathrm{H}$-score for PRA in stroma and PRB in the glands ( $p=0.0044$ for PRA in the stroma and $p=0.0376$ for PRB in glands) (Table IV). The presence or absence of PAX2 or PTEN mutations in the index biopsies did not show any association with relapse (Table V). All the control biopsies obtained after 3 months of therapy were also examined by immunohistochemistry and stained for ER $\alpha, \mathrm{ER} \beta, \mathrm{PRA}, \mathrm{PRB}, \mathrm{Bcl} 2, \mathrm{BAX}, \mathrm{PTEN}$ and PAX2. However, no statistical correlation was observed between relapse and any of the investigated markers (data not shown). 


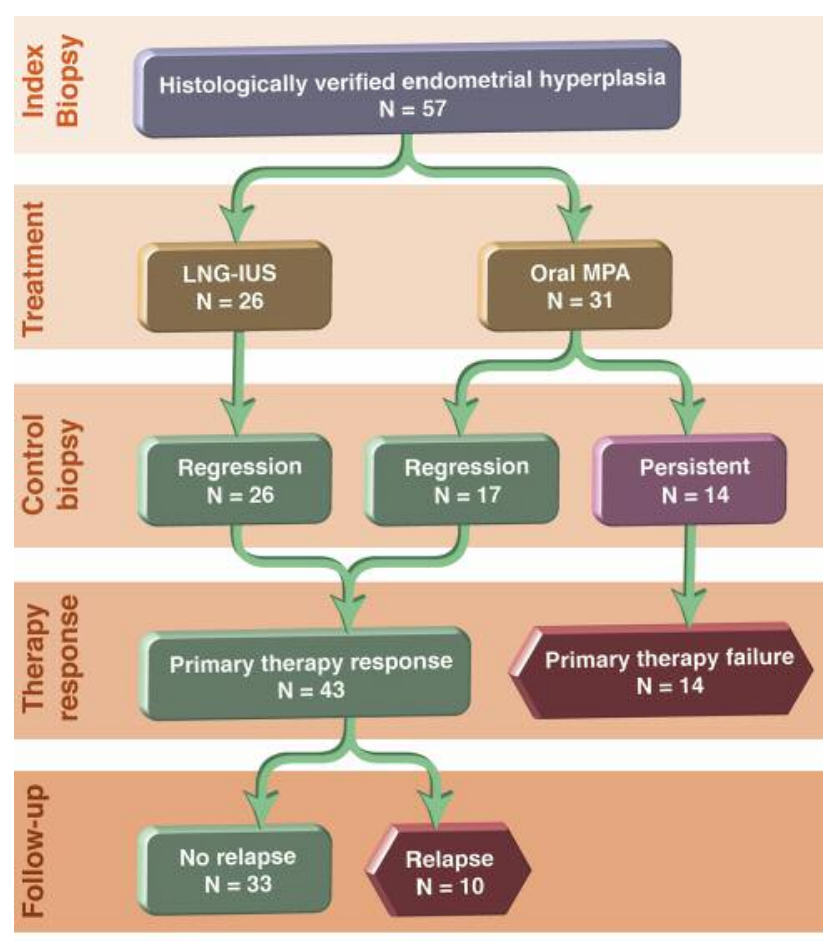

Figure 1. Flow chart illustrating the number of women included in the two treatment groups: The levonorgestrel-impregnated intrauterine system (LNG-IUS) (Mirena $\left.{ }^{\circledR}\right)$ for 3 months $(n=26)$ was compared with oral progestin therapy with medroxyprogesterone (MPA) $10 \mathrm{mg}$ daily for 10 days a month, repeated for three cycles $(n=31)$. Only women who responded after 3 months of therapy (43/57) were followed-up for relapse. Ten out of these 43 women experienced relapse.

\section{Discussion}

To the best of our knowledge, this observational cohort study of women with successfully treated low- and medium-risk endometrial hyperplasia has the longest follow-up ever reported after withdrawal of progestin therapy. During the observational period, which lasted up to 212 months, $23 \%$ of the women experienced relapse. However, the frequency of relapse in this study differed significantly from the results reported in our recent national randomized controlled trial which compared 6 months of treatment with intrauterine versus oral progestin. In that trial, $41 \%$ of the women had experienced relapse at 24 months of follow-up after withdrawal of therapy (25). There is no obvious reason for this difference, as the women in the two study groups were given similar therapy and were comparable with regards to age, BMI and parity (33). In the current study, the majority of relapses $(60 \%)$ were observed during the first 6 months after therapy was discontinued, but relapse was observed up to 10 years after withdrawal. This is consistent with the results of our randomized controlled trial, in which $70 \%$ of relapses occurred during the first 6 months,
Table II. Baseline characteristics of participants who underwent successful treatment of endometrial hyperplasia by the Levonorgestrelimpregnated intrauterine system (Mirena ${ }^{\circledR}$ ) or oral progestin, evaluated for prognostic significance. Significance levels are displayed as pvalues.

\begin{tabular}{lccc}
\hline Baseline characteristics & $\begin{array}{c}\text { Relapse } \\
(\mathrm{n}=10)\end{array}$ & $\begin{array}{c}\text { No relapse } \\
(\mathrm{n}=33)\end{array}$ & $p$-Value \\
\hline Mean age, years & 48.2 & 48.5 & 0.8937 \\
Mean parity & 2.2 & 2.3 & 0.8264 \\
0 & 1 & 3 & \\
1 & 2 & 4 & \\
2 & 4 & 13 & \\
$3+$ & 3 & 13 & 0.874 \\
BMI $\left(\mathrm{kg} / \mathrm{m}^{2}\right)^{*}$ & & & \\
WHO94 & 28.86 & 26.31 & 0.2508 \\
classification & & & \\
on index biopsy & & & 0.564 \\
CH & 7 & 26 & \\
AH & 3 & 7 & \\
& & & \\
D-Score on index biopsy** & & 10 & \\
$0-1$ & 6 & 23 & \\
$>1$ & 4 & & \\
\hline
\end{tabular}

BMI: Body mass index; AH: Complex atypical hyperplasia and simple atypical hyperplasia; $\mathrm{CH}$ : complex hyperplasia; $\mathrm{SH}$ : simple hyperplasia (3).*Missing for four patients in the No relapse group. **Morphometric $\mathrm{D}$-score predicting risk of malignant progression: D-score $<1$, low risk of endometrial cancer development; D-score 0-1, intermediate risk of cancer development $(17,29)$.

although relapses were diagnosed throughout the 24 months of observation (25). Another long-term follow-up cohort study of women with endometrial hyperplasia treated with progestin therapy reported relapse in five women 60 months after removal of the LNG-IUS (34). The present study showed a similar relapse frequency in the two treatment groups (LNGIUS vs. oral MPA). Another population-based observational study of 370 women with low- and medium-risk endometrial hyperplasia in northern Norway showed an average relapse frequency of $37 \%$ after LNG-IUS and $40 \%$ after oral progestin therapy, but no relapses were observed as long as the LNGIUS remained in situ (7). In contrast to our results, another long-term follow-up cohort study by Gallos and co-workers reported a relapse frequency of $13.7 \%$ after LNG-IUS but $30.3 \%$ after oral progestin therapy $(13,14)$. The higher frequency of relapse in the oral therapy group in that study was probably due to the shorter duration of therapy in the oral group (3-12 months) compared to the LNG-IUS group (5 years). Thus, the reported results clearly show the importance of long-term therapy with LNG-IUS to provide continuous endometrial protection and prevent relapse. 
Table III. Clinical and histological characteristics for the 10 women who experienced relapse of endometrial hyperplasia during the follow-up period after response to primary treatment.

\begin{tabular}{|c|c|c|c|c|c|c|c|}
\hline $\begin{array}{l}\text { Patient } \\
\text { ID }\end{array}$ & $\begin{array}{l}\text { Primary } \\
\text { therapy }\end{array}$ & $\begin{array}{c}\text { WHO94 } \\
\text { classification } \\
\text { on index biopsy }\end{array}$ & $\begin{array}{l}\text { D-Score on } \\
\text { index } \\
\text { biopsy** }\end{array}$ & $\begin{array}{c}\text { WHO } \\
\text { classification } \\
\text { at relapse* }\end{array}$ & $\begin{array}{l}\text { Months to diagnosis } \\
\text { of relapse after primary } \\
\text { treatment response }\end{array}$ & $\begin{array}{l}\text { Secondary } \\
\text { therapy }\end{array}$ & $\begin{array}{c}\text { Histology of } \\
\text { hysterectomy } \\
\text { specimen }\end{array}$ \\
\hline 1 & \multirow[t]{6}{*}{ LNG-IUS } & $\mathrm{CH}$ & $0-1$ & $\mathrm{AH}$ & 3 & Hysterectomy & $\mathrm{AH}$ \\
\hline 2 & & $\mathrm{AH}$ & $0-1$ & $\mathrm{CH}$ & 96 & Hysterectomy & Endometrial carcinoma $1 \mathrm{~A}$ \\
\hline 3 & & $\mathrm{CH}$ & $>1$ & SH & 4 & LNG-IUS & \\
\hline 4 & & $\mathrm{CH}$ & $0-1$ & $\mathrm{SH}$ & 6 & Unknown & \\
\hline 5 & & $\mathrm{CH}$ & $0-1$ & $\mathrm{CH}$ & 4 & Hysterectomy & $\mathrm{CH}$ \\
\hline 6 & & $\mathrm{CH}$ & $>1$ & $\mathrm{SH}$ & 2 & $\begin{array}{l}\text { Thermal balloon, } \\
\text { endometrial ablation }\end{array}$ & \\
\hline 7 & \multirow[t]{4}{*}{ MPA } & $\mathrm{AH}$ & $0-1$ & $\mathrm{AH}$ & 5 & Hysterectomy & $\mathrm{AH}$ \\
\hline 8 & & $\mathrm{CH}$ & $>1$ & $\mathrm{SH}$ & 21 & In vitro fertilization & \\
\hline 9 & & $\mathrm{AH}$ & $0-1$ & SH & 130 & LNG-IUS & \\
\hline 10 & & $\mathrm{CH}$ & $>1$ & $\mathrm{SH}$ & 36 & TCR & \\
\hline
\end{tabular}

*AH: Complex atypical hyperplasia and simple atypical hyperplasia; $\mathrm{CH}$ : complex hyperplasia; SH: simple hyperplasia (3); LNG-IUS: levonorgestrel-impregnated intrauterine system (Mirena ${ }^{\circledR}$ ); MPA: oral medroxyprogesterone administered at $10 \mathrm{mg}$ daily for 10 days per cycle; TCR: trans-cervical resection. **Morphometric D-score predicting risk of malignant progression: D-score $<1$, low risk of endometrial cancer development; D-score 0-1, intermediate risk of cancer development $(17,29)$.

Table IV. Biomarker expression levels, as evaluated by the H-score, in the index endometrial biopsies of women who relapsed vs. those who did not. Immunohistochemical expression was evaluated separately in glands and in the stroma.

\begin{tabular}{|c|c|c|c|c|}
\hline \multirow[b]{2}{*}{ Biomarker } & \multicolumn{4}{|c|}{ H-Score (mean) } \\
\hline & Location & Relapse, $\mathrm{N}=10$ & No relapse, $\mathrm{N}=33$ & $p$-Value \\
\hline \multirow[t]{2}{*}{ Progesterone receptor $A^{*}$} & Glands & 2.63 & 2.58 & 0.72 \\
\hline & Stroma & 1.43 & 2.21 & 0.0044 \\
\hline \multirow[t]{2}{*}{ Progesterone receptor $\mathrm{B}^{*}$} & Glands & 2.48 & 1.90 & 0.0376 \\
\hline & Stroma & 0.57 & 0.88 & 0.149 \\
\hline \multirow[t]{2}{*}{ Estrogen receptor $\alpha^{* *}$} & Glands & 1.81 & 1.59 & 0.48 \\
\hline & Stroma & 0.66 & 1.13 & 0.0697 \\
\hline \multirow[t]{2}{*}{ Estrogen receptor $\beta^{*}$} & Glands & 1.79 & 1.66 & 0.637 \\
\hline & Stroma & 1.54 & 1.29 & 0.331 \\
\hline \multirow[t]{2}{*}{ B-Cell lymphoma $2 * *$} & Glands & 1.72 & 1.87 & 0.5689 \\
\hline & Stroma & No expression & No expression & -- \\
\hline \multirow[t]{2}{*}{ B-Cell lymphoma 2-associated X protein* } & Glands & 1.27 & 1.2 & 0.7929 \\
\hline & Stroma & 0.43 & 0.42 & 0.9762 \\
\hline
\end{tabular}

Due to insufficient material in the paraffin blocks, immunohistochemistry was not performed for *one of the index biopsies in the relapse group and for five biopsies in the No relapse group, and **for one of the index biopsies in the Relapse group and for six biopsies in the No relapse group.

There is an ongoing search for clinical and biological biomarkers that could predict a high risk of relapse and help to select patients who would benefit from an extended duration of therapy and closer surveillance after completion of therapy. A cohort study by Gallos and co-workers reported that BMI $>35 \mathrm{~kg} / \mathrm{m}^{2}$ was a strong independent predictor of relapsing endometrial hyperplasia, conferring a threefold higher risk of relapse compared to patients with BMI $<35 \mathrm{~kg} / \mathrm{m}^{2}$ (13). In our current study, BMI, age and parity prior to treatment had no value in predicting relapse. Interestingly, the predictive value of the D-score on the index biopsy approached statistical significance $(p=0.08)$, whereas WHO classification showed no association with the risk of relapse (3).

To date, no study has reported an ideal marker for relapse based on index biopsy (35). A limited number of immunohistochemical markers have been reported in longitudinal studies to identify biomarkers associated with progestin resistance or progression but most of these studies evaluated changes before and immediately after therapy $(23,27$, 30, 36, 37). Akesson and co-workers reported significantly higher $\mathrm{H}$-scores for ERs and PRs in the index biopsies in responders to progestin therapy compared to non-responders 
Table V. Expression of phosphatase and tensin homolog (PTEN) and paired box 2 (PAX2) in the index endometrial biopsies of women with relapse versus those without. Immunohistochemical expression was evaluated only in glands.

\begin{tabular}{|c|c|c|c|}
\hline Prognostic variable & Relapse, $\mathrm{N}=10$ & No relapse, $\mathrm{N}=33$ & $p$-Value \\
\hline \multicolumn{4}{|l|}{$P T E N^{*}$} \\
\hline Mutation present & 5 & 19 & \\
\hline Mutation not present & 3 & 13 & 0.872 \\
\hline \multicolumn{4}{|l|}{$P A X 2^{*}$} \\
\hline Mutation present & 8 & 21 & \\
\hline Mutation not present & 0 & 11 & 0.051 \\
\hline
\end{tabular}

(36). Another study assessing the prognostic value of PRA, PRB, BCL2, PTEN and PAX2 in the index biopsy showed that high PRB expression was associated with $90 \%$ decreased risk of persistence or progression in atypical hyperplasia associated with LNG-IUS (22). Our results showed higher levels of glandular PRB and lower stromal PRA levels in the relapsing group compared to non-relapsing women. A recent in vitro study suggested that epigenetic de-repression of stromal PR could be a potential target for sensitizing hormone-refractory endometrial tumors to progesterone therapy and that stromal expression of PR might represent a reliable biomarker in predicting response to hormonal therapy (38). The clinical significance of these findings is not obvious, but continued progestin therapy with long-term use of LNG-IUS might have a therapeutic effect by continuously down-regulating PRB. In another long-term followup study assessing immunohisto-chemical expression of ER, PR, cyclo-oxygenases (COX2), defect DNA mismatch-repair mechanism (MLH1) and BCL2, none of the investigated biomarkers were found to be predictive of relapse in women treated for atypical and complex hyperplasia (35). The significance of the different PRA expression levels between women with relapse and those without remains to be explained, but the PRA isoform typically dominates the endometrial stroma (39). Expression levels of glandular and stromal PRA and PRB comparable to those of the present study were observed in a previous study that compared expression levels of these receptors before and after therapy (37).

In conclusion, women with endometrial hyperplasia may experience relapse after successful primary progestin therapy. Follow-up after response to therapy for endometrial hyperplasia must be continued for years after withdrawal of therapy. Increased levels of PRB in glands and low PRA levels in stromal cells were found to distinguish high-risk individuals from those with permanent remission, but randomized studies with larger samples will be necessary to confirm the prognostic value of these markers. Our results support the importance of long-term use of LNG-IUS to provide continuous endometrial protection and emphasize the need for new clinical surveillance guidelines.

\section{Acknowledgements}

We thank the Regional Research Board of Northern Norway (Helse Nord) for the grants. We also thank Roy A. Lysaa, M.Sc., Ph.D. for producing the artwork.

\section{References}

1 Okuda T, Sekizawa A, Purwosunu Y, Nagatsuka M, Morioka M, Hayashi M and Okai T: Genetics of endometrial cancers. Obstet Gynecol Int 2010: 984013, 2010.

2 Rodriguez AM, Schmeler KM and Kuo YF: Lack of improvement in survival rates for women under 50 with endometrial cancer, 2000-2011. J Cancer Res Clin Oncol 142: 783-793, 2016.

3 Kurman RJ, Kaminski PF and Norris HJ: The behavior of endometrial hyperplasia. A long-term study of "untreated" hyperplasia in 170 patients. Cancer 56: 403-412, 1985.

4 Clark TJ, Neelakantan D and Gupta JK: The management of endometrial hyperplasia: an evaluation of current practice. Eur J Obstet Gynecol Reprod Biol 125: 259-264, 2006.

5 Ferenczy A and Gelfand M: The biologic significance of cytologic atypia in progestogen-treated endometrial hyperplasia. Am J Obstet Gynecol 160: 126-131, 1989.

6 Jobo T, Kawaguchi M, Imai M and Kuramoto H: Treatment for complex atypical hyperplasia of the endometrium. Eur $\mathrm{J}$ Gynaecol Oncol 22: 365-368, 2001.

7 Orbo A, Arnes M, Hancke C, Vereide AB, Pettersen I and Larsen $\mathrm{K}$ : Treatment results of endometrial hyperplasia after prospective D-score classification: a follow-up study comparing effect of LNG-IUD and oral progestins versus observation only. Gynecol Oncol 111: 68-73, 2008.

8 Buttini MJ, Jordan SJ and Webb PM: The effect of the levonorgestrel releasing intrauterine system on endometrial hyperplasia: an Australian study and systematic review. Aust $\mathrm{N}$ Z J Obstet Gynaecol 49: 316-322, 2009.

9 Gallos ID, Shehmar M, Thangaratinam S, Papapostolou TK, Coomarasamy A and Gupta JK: Oral progestogens vs. levonorgestrel-releasing intrauterine system for endometrial hyperplasia: a systematic review and metaanalysis. Am J Obstet Gynecol 203: 547-510, 2010.

10 Orbo A, Baak JP, Kleivan I, Lysne S, Prytz PS, Broeckaert MA, Slappendel A and Tichelaar HJ: Computerised morphometrical analysis in endometrial hyperplasia for the prediction of cancer development. A long-term retrospective study from northern Norway. J Clin Pathol 53: 697-703, 2000.

11 Varma R, Soneja H, Bhatia K, Ganesan R, Rollason T, Clark TJ and Gupta JK: The effectiveness of a levonorgestrel-releasing intrauterine system (LNG-IUS) in the treatment of endometrial hyperplasia-a long-term follow-up study. Eur J Obstet Gynecol Reprod Biol 139: 169-175, 2008.

12 Wildemeersch D, Janssens D, Pylyser K, De WN, Verbeeck G, Dhont $\mathrm{M}$ and Tjalma W: Management of patients with nonatypical and atypical endometrial hyperplasia with a levonorgestrel-releasing intrauterine system: long-term followup. Maturitas 57: 210-213, 2007. 
13 Gallos ID, Ganesan R and Gupta JK: Prediction of regression and relapse of endometrial hyperplasia with conservative therapy. Obstet Gynecol 121: 1165-1171, 2013.

14 Gallos ID, Krishan P, Shehmar M, Ganesan R and Gupta JK: LNG-IUS versus oral progestogen treatment for endometrial hyperplasia: a long-term comparative cohort study. Hum Reprod 28: 2966-2971, 2013.

15 Allison KH, Tenpenny E, Reed SD, Swisher EM and Garica RL: Immunohistochemical markers in endometrial hyperplasia: is there a panel with promise? A review. Appl Immunohistochem Mol Morphol 16: 329-343, 2008.

16 Miyamoto T, Watanabe J, Hata H, Jobo T, Kawaguchi M, Hattori M, Saito $M$ and Kuramoto $H$ : Significance of progesterone receptor-A and -B expressions in endometrial adenocarcinoma. J Steroid Biochem Mol Biol 92: 111-118, 2004.

17 Mutter GL, Baak JP, Crum CP, Richart RM, Ferenczy A and Faquin WC: Endometrial precancer diagnosis by histopathology, clonal analysis and computerized morphometry. J Pathol 190: 462-469, 2000.

18 Mutter GL, Lin MC, Fitzgerald JT, Kum JB, Baak JP, Lees JA, Weng LP and Eng C: Altered PTEN expression as a diagnostic marker for the earliest endometrial precancers. J Natl Cancer Inst 92: 924-930, 2000.

19 Quick CM, Laury AR, Monte NM and Mutter GL: Utility of PAX2 as a marker for diagnosis of endometrial intraepithelial neoplasia. Am J Clin Pathol 138: 678-684, 2012.

20 Strissel PL, Ellmann S, Loprich E, Thiel F, Fasching PA, Stiegler E, Hartmann A, Beckmann MW and Strick R: Early aberrant insulin-like growth factor signaling in the progression to endometrial carcinoma is augmented by tamoxifen. Int $\mathrm{J}$ Cancer 123: 2871-2879, 2008.

21 Amezcua CA, Zheng W, Muderspach LI and Felix JC: Downregulation of bcl-2 is a potential marker of the efficacy of progestin therapy in the treatment of endometrial hyperplasia. Gynecol Oncol 73: 126-136, 1999.

22 Upson K, Allison KH, Reed SD, Jordan CD, Newton KM, Swisher EM, Doherty JA and Garcia RL: Biomarkers of progestin therapy resistance and endometrial hyperplasia progression. Am J Obstet Gynecol 207: 36-38, 2012.

23 Vereide AB, Kaino T, Sager G and Orbo A: BCL-2, BAX and apoptosis in endometrial hyperplasia after high dose gestagen therapy: a comparison of responses in patients treated with intrauterine levonorgestrel and systemic medroxyprogesterone. Gynecol Oncol 97: 740-750, 2005.

24 Monte NM, Webster KA, Neuberg D, Dressler GR and Mutter GL: Joint loss of PAX2 and PTEN expression in endometrial precancers and cancer. Cancer Res 70: 6225-6232, 2010.

25 Orbo A, Arnes M, Vereide AB and Straume B: Relapse risk of endometrial hyperplasia after treatment with the levonorgestrelimpregnated intrauterine system or oral progestogens. BJOG 123: 1512-1519, 2016.

26 Orbo A, Rise CE and Mutter GL: Regression of latent endometrial precancers by progestin infiltrated intrauterine device. Cancer Res 66: 5613-5617, 2006.

27 Amezcua CA, Lu JJ, Felix JC, Stanczyk FZ and Zheng W: Apoptosis may be an early event of progestin therapy for endometrial hyperplasia. Gynecol Oncol 79: 169-176, 2000.

28 Baak JP, Mutter GL, Robboy S, van Diest PJ, Uyterlinde AM, Orbo A, Palazzo J, Fiane B, Lovslett K, Burger C, Voorhorst F and Verheijen RH: The molecular genetics and morphometry- based endometrial intraepithelial neoplasia classification system predicts disease progression in endometrial hyperplasia more accurately than the 1994 World Health Organization classification system. Cancer 103: 2304-2312, 2005.

29 Baak JP, Nauta JJ, Wisse-Brekelmans EC and Bezemer PD: Architectural and nuclear morphometrical features together are more important prognosticators in endometrial hyperplasias than nuclear morphometrical features alone. J Pathol 154: 335-341, 1988.

30 Orbo A, Arnes M, Pettersen I, Larsen K, Hanssen K and Moe B: Down-regulated progesterone receptor $\mathrm{A}$ and $\mathrm{B}$ coinciding with successful treatment of endometrial hyperplasia by the levonorgestrel impregnated intrauterine system. Acta Obstet Gynecol Scand 89: 1438-1446, 2010.

31 Huang A, Pettigrew NM and Watson PH: Immunohistochemical assay for oestrogen receptors in paraffin wax sections of breast carcinoma using a new monoclonal antibody. J Pathol 180: 223227, 1996.

32 Vereide AB, Arnes M, Straume B, Maltau JM and Orbo A: Nuclear morphometric changes and therapy monitoring in patients with endometrial hyperplasia: a study comparing effects of intrauterine levonorgestrel and systemic medroxyprogesterone. Gynecologic Oncology 91: 526-533, 2003.

33 Orbo A, Vereide A, Arnes M, Pettersen I and Straume B: Levonorgestrel-impregnated intrauterine device as treatment for endometrial hyperplasia: a national multicentre randomised trial. BJOG 121: 477-486, 2014.

34 Gallos ID, Krishan P, Shehmar M, Ganesan R and Gupta JK: Relapse of endometrial hyperplasia after conservative treatment: a cohort study with long-term follow-up. Hum Reprod 28: 12311236, 2013.

35 Gallos ID, Devey J, Ganesan R and Gupta JK: Predictive ability of estrogen receptor (ER), progesterone receptor (PR), COX-2, Mlh1 and Bcl-2 expressions for regression and relapse of endometrial hyperplasia treated with LNG-IUS: a prospective cohort study. Gynecol Oncol 130: 58-63, 2013.

36 Akesson E, Gallos ID, Ganesan R, Varma R and Gupta JK: Prognostic significance of estrogen and progesterone receptor expression in LNG-IUS (Mirena) treatment of endometrial hyperplasia: an immunohistochemical study. Acta Obstet Gynecol Scand 89: 393-398, 2010.

37 Vereide AB, Kaino T, Sager G, Arnes M and Orbo A: Effect of levonorgestrel IUD and oral medroxyprogesterone acetate on glandular and stromal progesterone receptors (PRA and PRB) and estrogen receptors (ER-alpha and ER-beta) in human endometrial hyperplasia. Gynecol Oncol 101: 214-223, 2006.

38 Janzen DM, Rosales MA, Paik DY, Lee DS, Smith DA, Witte $\mathrm{ON}$, Iruela-Arispe ML and Memarzadeh S: Progesterone receptor signaling in the microenvironment of endometrial cancer influences its response to hormonal therapy. Cancer Res 73: 4697-4710, 2013.

39 Mote PA, Balleine RL, McGowan EM and Clarke CL: Heterogeneity of progesterone receptors A and B expression in human endometrial glands and stroma. Hum Reprod 15(Suppl 3): 48-56, 2000. 